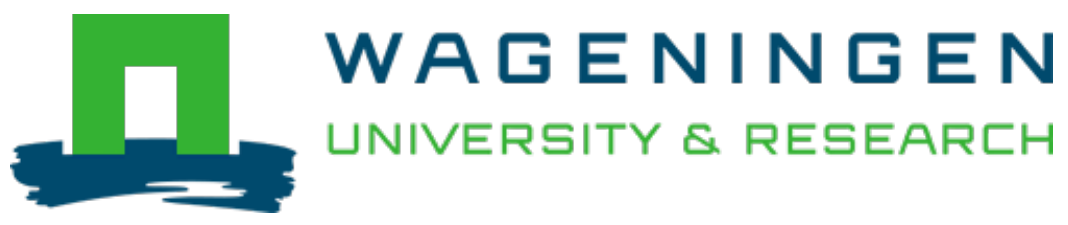

\title{
Effect of environmental conditions during soya-bean fermentation on the growth of Staphylococcus aureus and production and thermal stability of enterotoxins A and $\mathrm{B}$
}

\author{
International Journal of Food Microbiology \\ Nout, M.J.R.; Notermans, S.; Rombouts, F.M. \\ https://doi.org/10.1016/0168-1605(88)90056-6
}

This publication is made publicly available in the institutional repository of Wageningen University and Research, under the terms of article $25 \mathrm{fa}$ of the Dutch Copyright Act, also known as the Amendment Taverne. This has been done with explicit consent by the author.

Article $25 \mathrm{fa}$ states that the author of a short scientific work funded either wholly or partially by Dutch public funds is entitled to make that work publicly available for no consideration following a reasonable period of time after the work was first published, provided that clear reference is made to the source of the first publication of the work.

This publication is distributed under The Association of Universities in the Netherlands (VSNU) 'Article $25 \mathrm{fa}$ implementation' project. In this project research outputs of researchers employed by Dutch Universities that comply with the legal requirements of Article 25fa of the Dutch Copyright Act are distributed online and free of cost or other barriers in institutional repositories. Research outputs are distributed six months after their first online publication in the original published version and with proper attribution to the source of the original publication.

You are permitted to download and use the publication for personal purposes. All rights remain with the author(s) and / or copyright owner(s) of this work. Any use of the publication or parts of it other than authorised under article $25 \mathrm{fa}$ of the Dutch Copyright act is prohibited. Wageningen University \& Research and the author(s) of this publication shall not be held responsible or liable for any damages resulting from your (re)use of this publication.

For questions regarding the public availability of this publication please contact openscience.library@wur.nl 


\title{
Effect of environmental conditions during soya-bean fermentation on the growth of Staphylococcus aureus and production and thermal stability of enterotoxins $\mathrm{A}$ and $\mathrm{B}$
}

\author{
M.J.R. Nout ${ }^{1}$, S. Notermans ${ }^{2}$ and F.M. Rombouts ${ }^{1}$ \\ ${ }^{I}$ Department of Food Science, Agricultural University, Wageningen, The Netherlands \\ and ${ }^{2}$ Laboratory of Water and Food Microbiology, National Institute of Public Health \\ and Environmental Protection, Bilthoven, The Netherlands
}

(Received 20 May 1988; accepted 7 September 1988)

\begin{abstract}
During tempe manufacture, Staphylococcus aureus was able to survive in newly started soya-bean soaks (final pH 4.7), whereas it died during soaks with accelerated souring (final pH 4.0). No $S$. aureus were detected after subsequent heat treatment of soaked beans. $S$. aureus strain $\mathbf{S 6}$ could produce enterotoxins $A$ and $B$ if inoculated on cooked soya-beans. Its growth and enterotoxin production were not influenced by inoculation rate nor by the presence of actively growing Rhizopus oligosporus, the fungus responsible for tempe formation. Enterotoxin levels were highest after $48 \mathrm{~h}$ fermentation. Presence of lactobacilli ( $L$. brevis or $L$ plantarum) during the tempe fermentation did not influence staphylococcal growth, but enterotoxin levels were reduced. Reduced oxygen pressure did not affect staphylococcal growth, but resulted in lower enterotoxin levels after $48 \mathrm{~h}$ incubation. The thermal stability of enterotoxin $A$ in tempe was significantly lower than in Brain Heart Infusion broth of comparable pH. Heating of enterotoxincontaining tempe mash reduced enterotoxin A by $99.7 \%$ as measured with ELISA and animal feeding methods.
\end{abstract}

Key words: Staphylococcus aureus growth; Staphylococcal enterotoxins; Thermal stability; Tempe; Soya-bean; Fermented products

\section{Introduction}

Tempe is a legume- or cereal-based food obtained by fungal solid-state fermentation. Soya-bean tempe originated in Indonesia and presently meets an increasing interest in other regions as well. The manufacturing process has been reviewed extensively (Ko and Hesseltine, 1979). It includes soaking dehulled soya-beans in water overnight, followed by boiling or steaming, discarding the boiled water,

Correspondence address: M.J.R. Nout, Department of Food Science, Agricultural University, Bomenweg 2, 6703 HD Wageningen, The Netherlands. 


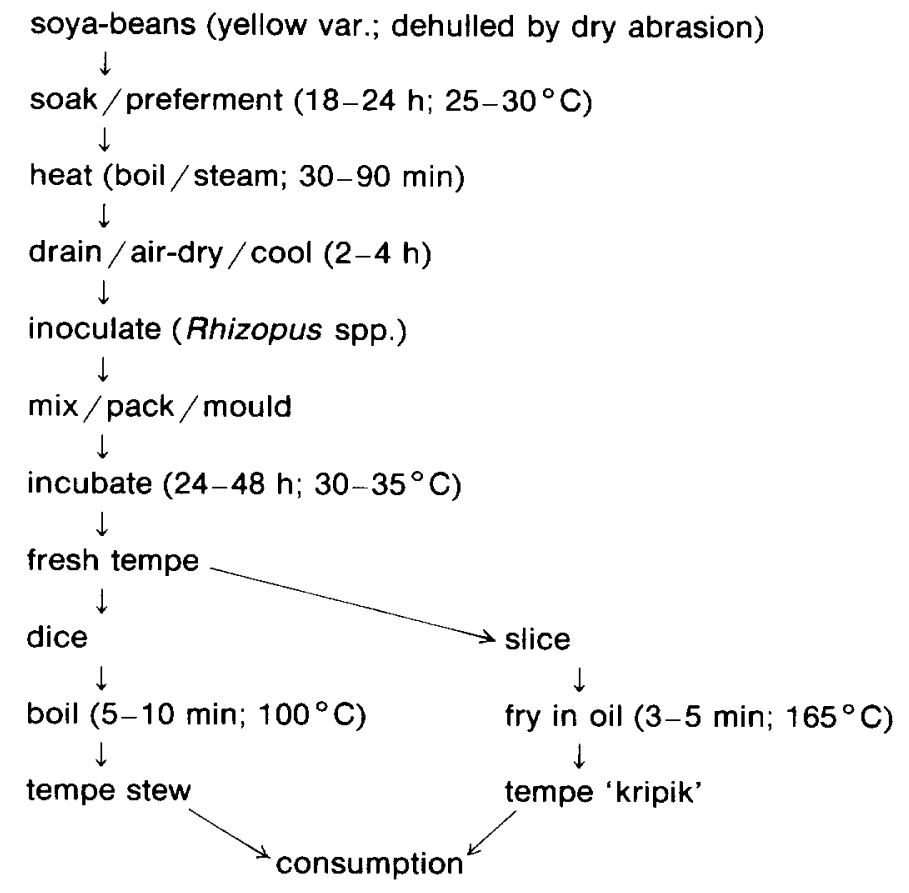

Fig. 1. Tempe manufacture and preparation for consumption.

allowing the beans to air-dry and cool, inoculating them with spore preparations of Rhizopus spp., usually $R$. oligosporus, and fermenting the inoculated beans in perforated containers (Fig. 1). The resulting fresh tempe is a firm mass of beans and fungal mycelium which has not sporulated due to the limited oxygen supply. This product has a limited shelf-life and should be prepared for consumption the same day or be kept refrigerated. Preparation prior to consumption consists of heating, e.g. boiling in stew or frying in oil.

The nutrient composition, high water activity and neutral $\mathrm{pH}$ of fresh soya-bean tempe provide a suitable environment for large numbers of bacteria and yeasts accompanying the fungal mycelium. A survey of commercial tempe (Samson et al., 1987) revealed the presence of Bacillus cereus and Staphylococcus aureus ( $>4 \log$ $\mathrm{CFU} / \mathrm{g}$ in $12 \%$ and $16 \%$ of all samples, respectively).

$B$. cereus was shown (Nout et al., 1987a) to grow rapidly to $8-9 \log \mathrm{CFU} / \mathrm{g}$ tempe made from non-acidified beans. On the other hand, its growth was inhibited if beans had been acidified to $\mathrm{pH} \leqslant 4.85$ by previous lactic acid fermentation.

This paper presents data on growth and production and stability of enterotoxins of $S$. aureus during the various stages of tempe manufacture and preparation. It was observed that growth and production of enterotoxin occurs during processing of $S$. aureus inoculated soya-beans. However, the enterotoxin produced was inactivated during heat treatment. 


\section{Materials and Methods}

\section{Micro-organisms}

Staphylococcus aureus: strain 1 was isolated by us from commercial tempe; 196E (producer of staphylococcal enterotoxin A (SEA), FRI913 (SEA), S6 (SEA + SEB), FRI722 (SEB) and 14458 (SEB) were obtained from the collection of the National Institute of Public Health and Environmental Protection, Bilthoven, The Netherlands. Strains were maintained on Nutrient Agar slants (Oxoid CM3) at $4^{\circ} \mathrm{C}$, after having been incubated 2 days at $37^{\circ} \mathrm{C}$. Inoculation of food samples was carried out with young cultures in Brain Heart Infusion broth (BHI) (Gibco, Scotland, No. 152-0680) which had been incubated 2 days at $37^{\circ} \mathrm{C}$.

Rhizopus oligosporus: strain NRRL5909 was used. Cultivation, and preparation of spore suspensions were carried out as described previously (Nout et al., 1987a).

Lactobacillus brevis and L. plantarum which had been isolated previously (Nout et al., 1987b) from fermenting soya-beans were grown in de Man, Rogosa and Sharpe broth (MRS; Gibco, Scotland, No. 152-3250) for $24 \mathrm{~h}$ at $25^{\circ} \mathrm{C}$.

\section{Test samples}

Soya-bean soaks: freshly started soaks and soaks with accelerated souring were carried out as described previously by Nout et al. (1987b) as soak for spontaneous fermentation and soak with recycling procedure, respectively. Inoculation with a 24 h $37^{\circ} \mathrm{C} \mathrm{BHI}$ culture of $S$. aureus was carried out at the start of the soaking operation.

Cooked soya-beans and tempe: for tempe manufacture, we used the method as published previously (Nout et al., 1987b) employing a soak for spontaneous fermentation. If cooked soya-beans were to be tested, they were transferred aseptically into sterile petri dishes after cooling to ambient temperature, giving a single layer of beans to prevent heat and mass transfer limitations. Inoculation was carried out by adding appropriate dilutions of $R$. oligosporus, $S$. aureus, L. brevis or $L$. plantarum cultures to the beans, followed by mixing with a sterile spoon. Incubation was at $30^{\circ} \mathrm{C}$ for $48 \mathrm{~h}$. The influence of reduced oxygen pressure was studied by incubation in jars flushed with a gas mixture of $98 \% \mathrm{~N}_{2}$ and $2 \% \mathrm{O}_{2}$ humified by percolation through sterile distilled water at a flow rate of $51 / \mathrm{h}$. The $\mathrm{O}_{2}$ concentration in the exhaust gas was $>90 \%$ of that of the mixture entering the jars. Production of enterotoxin in tempe was carried out by inoculating the cooked soya-beans with $R$. oligosporus and $\boldsymbol{S}$. aureus during the tempe manufacturing process. Fresh, contaminated tempe $(40 \mathrm{~g})$ was homogenized for $2 \mathrm{~min}$ in a Colworth type 400 Stomacher (Seward \& Co., London) with $80 \mathrm{ml}$ PBST (mix $0.07 \mathrm{M} \mathrm{NaH}_{2} \mathrm{PO}_{4}$ solution in $0.15 \mathrm{M} \mathrm{NaCl}$ with $0.07 \mathrm{M} \mathrm{Na}_{2} \mathrm{HPO}_{4}$ in $0.15 \mathrm{M} \mathrm{NaCl}$ to obtain pH 7.2, add $0.05 \%$ Tween 20 , sterilize $15 \mathrm{~min} 121^{\circ} \mathrm{C}$ ) prior to experimental heat treatment. Addition of staphylococcal enterotoxin A to non-contaminated fresh tempe was carried out by homogenizing $75 \mathrm{~g}$ tempe, $75 \mathrm{ml} \mathrm{PBST}$, and $750 \mu \mathrm{g}$ enterotoxin A for $2 \mathrm{~min}$ in a Colworth type $\mathbf{4 0 0}$ Stomacher to obtain a mash suitable for experimental heat treatment. 


\section{Heat treatments}

Heat treatments were carried out at 80,100 , and $125^{\circ} \mathrm{C}$ in a thermostat-controlled glycerol bath in sealed $5 \mathrm{~mm}$ inner diameter borosilicate glass tubes (wall thickness $1 \mathrm{~mm}$ ) containing $3 \mathrm{ml}$ or $3 \mathrm{~g}$ mashed sample. Temperatures were monitored using copperconstantane thermocouples placed in the centre of the sample with a centering device.

Analysis

\section{Microbiological analysis}

Sample preparation: representative samples of $10.0 \mathrm{~g}$ were homogenized for $2 \mathrm{~min}$ with $90 \mathrm{ml}$ of sterile peptone saline using a Colworth type 400 Stomacher. Decimal dilution series were prepared using tubes with $9 \mathrm{ml}$ of sterile peptone saline.

S. aureus: surface counts on Baird-Parker agar (BP, Gibco, Scotland, No. 152-0320) sterilized $15 \mathrm{~min}$ at $121^{\circ} \mathrm{C}$ supplemented with $10 \mathrm{ml}$ filter-sterilized $0.1 \%$ $\mathrm{K}_{2} \mathrm{TeO}_{3}$, and $50 \mathrm{ml} 10 \mathrm{kGy} \gamma$-irradiated $10 \%$ egg yolk suspension in $0.85 \% \mathrm{NaCl}$ respectively, per $940 \mathrm{ml}$ of basal medium. Incubation 2 days at $37^{\circ} \mathrm{C}$. All black colonies with or without white margin and clear halo were counted as $S$. aureus. Occasionally, confirmations were performed by carrying out coagulase tests (Bacto coagulase plasma EDTA, Difco, 083-46-5).

$R$. oligosporus: surface counts on Rose Bengal Chloramphenicol Chlortetracyclin Agar with increased rose bengal concentration according to Baggerman (1981). Incubation 2-3 days at $30^{\circ} \mathrm{C}$.

Lactobacilli: pour plate counts with overlay in Rogosa agar (LBS agar BBL No. 11327, Becton Dickinson \& Co.) supplemented with $0.2 \%$ natamycin (Delvocid, Gist-Brocades, Delft, The Netherlands) to suppress the growth of yeasts. Incubation 3 days at $30^{\circ} \mathrm{C}$. Counts were corrected by microscopic confirmation of $\downarrow$ randomly chosen colonies.

Reporting of counts: as previously described (Nout et al., 1987a).

Staphylococcal enterotoxins: the amounts of enterotoxins A and B were determined using a direct sandwich ELISA procedure, as described by Notermans et al. (1983a). Microtiter wells were coated with $0.1 \mathrm{ml}$ immunoglobin (IgG) solution in phosphate buffered saline (PBS: $\operatorname{mix} 0.07 \mathrm{M} \mathrm{NaH}_{2} \mathrm{PO}_{4}$ solution in $0.15 \mathrm{M} \mathrm{NaCl}$ with $0.07 \mathrm{M} \mathrm{Na}_{2} \mathrm{HPO}_{4}$ in $0.15 \mathrm{M} \mathrm{NaCl}$ to obtain $\mathrm{pH} 7.2$, sterilize $15 \mathrm{~min}$ at $121^{\circ} \mathrm{C}$ ) for $17 \mathrm{~h}$ at ambient temperature on an orbital shaker at $60 \mathrm{rpm}$. IgG-anti-SEA: 3-5 $\mu \mathrm{g} / \mathrm{ml}$ PBS; IgG-anti-SEB: $10 \mu \mathrm{g} / \mathrm{ml}$ PBS (monoclonal as well as polyclonal sets of IgGs and conjugates were used). Rinse 3 times with PBST. Add to each well $0.1 \mathrm{ml}$ sample, diluted in PBST. Incubate at ambient temperature at $60 \mathrm{rpm}$ for $1.5 \mathrm{~h}$. Rinse 3 times with PBST. Add to each well $0.1 \mathrm{ml} \mathrm{IgG-peroxidase} \mathrm{conjugate}$ $(\mathrm{IgG}=\mathrm{Po}$ ), dissolved in PBST (optimum concentration was determined by checkerboard titration). Incubate as with sample. Rinse as above, 3 times. Add $0.1 \mathrm{ml}$ enzyme substrate $(0.08 \% 5$-aminosalicylic acid in dist. water, $\mathrm{pH} 6.0$, to which $20 \mu \mathrm{l}$ $30 \% \mathrm{H}_{2} \mathrm{O}_{2}$ was added) and read extinction at $450 \mathrm{~nm}$ after $30 \mathrm{~min}$ using an ELISA-reader (EAR 400, SLT-Labinstruments, Austria). Each microtiter plate 
included 6 blank wells and 6 wells containing known concentrations of pure enterotoxin. Quantification was based on interpolations on a dose-response calibration curve which was re-adjusted for each plate. Detection levels (99\% significant difference from mean of blanks) of both enterotoxins A and B was $0.8 \mathrm{ng} / \mathrm{ml}$.

Biological activity of enterotoxin $A$ : two cynomolgus monkeys (Macaca fascicularis) of $2-2.5 \mathrm{~kg}$ body weight were each fed $20 \mathrm{ml}$ supernatant of heat treated tempe mash as described by Notermans et al. (1987).

\section{Results and Discussion}

During a non-sterile traditional tempe manufacturing process, the first operation is the soaking of the beans. Variations notwithstanding, each newly started soak will be dominated by Enterobacteriaceae and later by lactic acid bacteria; the $\mathrm{pH}$ will decrease from approx. 6.5 to values between 4 and 6, usually between 4.5 and 5.5 . However, $\mathrm{pH}$ values $\leqslant 4.0$ are obtained during soaking with accelerated souring, achieved by recycling of soak water (Nout et al., 1987b). Table I shows that $S$. aureus is able to survive in newly started soaks, whereas it dies during soaks with accelerated souring. This is in line with the earlier finding (Notermans and Heuvelman, 1983b) that $S$. aureus can grow at $\mathrm{pH} \geqslant 4.6$.

After boiling, draining, air-drying and cooling of the soaked beans, their microbiological content depends very much on processing and handling conditions. During our laboratory experiments we could not detect the presence of $S$. aureus in cooked beans using surface plate count on Baird-Parker medium.

During the inoculation, mixing and moulding stages of the manufacturing process, the practically sterile cooked beans are subjected to chance contaminations from equipment, handling, substandard inoculum, etc. In addition, during the fungal fermentation phase the growth and enterotoxin production of $S$. aureus could be expected to be influenced by several factors, i.e. the initial $\mathrm{pH}$ and organic acids

\section{TABLE 1}

Growth of Staphylococcus aureus strain 1 during soya-bean soaking (soya-beans $1 \mathrm{~kg}+\operatorname{tapwater} 3 \mathrm{~kg}$; soaking $18 \mathrm{~h}$ at $25^{\circ} \mathrm{C}$ )

\begin{tabular}{lcc}
\hline $\begin{array}{l}\text { Initial contamination } \\
\text { with } S . \text { aureus } \text { strain } 1 \\
\text { (log CFU } / g)\end{array}$ & $\begin{array}{l}\text { Final pH of } \\
\text { soak water }\end{array}$ & $\begin{array}{l}\text { S. aureus } \text { in } \\
\text { soaked beans } \\
(\log \text { CFU } / g)\end{array}$ \\
\hline $\begin{array}{l}\text { Freshly started soak with spontaneous fermentation: } \\
\text { not inoculated (control) }\end{array}$ & 4.9 & 2.86 \\
6.76 & 4.7 & 7.10 \\
Soak with accelerated souring using recycling & ${ }^{\mathrm{a}}:$ & \\
not inoculated (control) & 4.0 & $<2.70$ \\
4.52 & 4.0 & $<2.70$ \\
\hline
\end{tabular}

${ }^{a}$ Nout et al. (1987b). 
present in the beans; the presence of competing micro-organisms (Notermans et al., 1984); and the reduced availability of oxygen (Barber and Deibel, 1972). In order to eliminate growth limitations which might arise from the use of beans soaked with accelerated souring, we used beans from freshly started soaks in all following experiments, unless stated otherwise.

The production of staphylococcal enterotoxins (SEA and SEB) of $S$. aureus strains 196E (SEA), FRI913 (SEA), S6 (SEA and SEB), FRI722 (SEB) and 14458 (SEB) was tested and confirmed in BHI cultures and on chicken meat. On cooked soya-beans, strains 196E and FRI913 did not produce enterotoxin. Strain S6 was selected for further experiments because of its production of both SEA and SEB on soya-beans.

Table II shows that there is no significant effect of the rate of contamination with $S$. aureus strain $\mathrm{S} 6$ on its growth in beans without or with $R$. oligosporus. Also the growth of $R$. oligosporus is not influenced by the presence of growing $S$. aureus. Storage $\left(5\right.$ days at $7^{\circ} \mathrm{C}$ ) of the $48 \mathrm{~h}$ fermented samples did not significantly affect the numbers of viable $S$. aureus and $R$. oligosporus (data not shown). Staphylococcal enterotoxins $A$ and B produced by $S$. aureus strain $S 6$ could be detected already after $24 \mathrm{~h}$. Their quantities were quite variable. From the results, no significant effect could be observed of initial $S$. aureus contamination rate or presence of $R$. oligosporus. In most samples the enterotoxin A and B content was highest after $48 \mathrm{~h}$ fermentation. Six fermented samples were analyzed after 5 days storage at $7^{\circ} \mathrm{C} ; 3$ samples had significantly lower SEA levels after storage $(8,3$ and $128 \mathrm{ng} / \mathrm{g})$ compared to their SEA levels before storage (208, 74 and $670 \mathrm{ng} / \mathrm{g}$, respectively). Other SEA or SEB levels were not affected.

Table III summarizes the effect of Lactobacillus brevis and L. plantarum during the fungal fermentation stage. Both strains had been isolated earlier (Nout et al., $1987 \mathrm{~b}$ ) from soaks with accelerated souring; L. plantarum was shown to contribute to the quality of fresh tempe. The presence of $S$. aureus strain $\mathrm{S} 6$ and $R$. oligosporus alone (Table III, treatment B) resulted in staphylococcal growth and enterotoxin production comparable to the data in Table II. The additional presence and growth of $L$. brevis (Table III, treatment C) and L. plantarum (Table III, treatment D) did not significantly influence staphylococcal growth; the $\mathrm{pH}$ of the product was slightly reduced after 48 hours. Nevertheless, the presence of the lactobacilli resulted in lower enterotoxin $\mathbf{A}$ and $\mathbf{B}$ levels. As yet, insufficient data are available to speculate on the role of the lactobacilli in the reduction of enterotoxin levels in fermented tempe.

Whereas the above experiments had been carried out under aerobic atmospheric conditions, the influence of reduced oxygen availability occurring in the centre of fermenting tempe mass (Rathbun and Shuler, 1983) was investigated in an incubator flushed with $98 \% \mathrm{~N}_{2}+2 \% \mathrm{O}_{2}$ gas mixture. Table IV shows that under conditions of reduced oxygen pressure, growth of $S$. aureus strain $S 6$ was not inhibited, but considerably less enterotoxin A was produced. This is in line with the findings of Barber and Deibel (1972). From the above it is concluded that the presence of lactobacilli and a reduced oxygen transfer during the tempe fermentation will result in reduced enterotoxin levels in $S$. aureus contaminated tempe. 


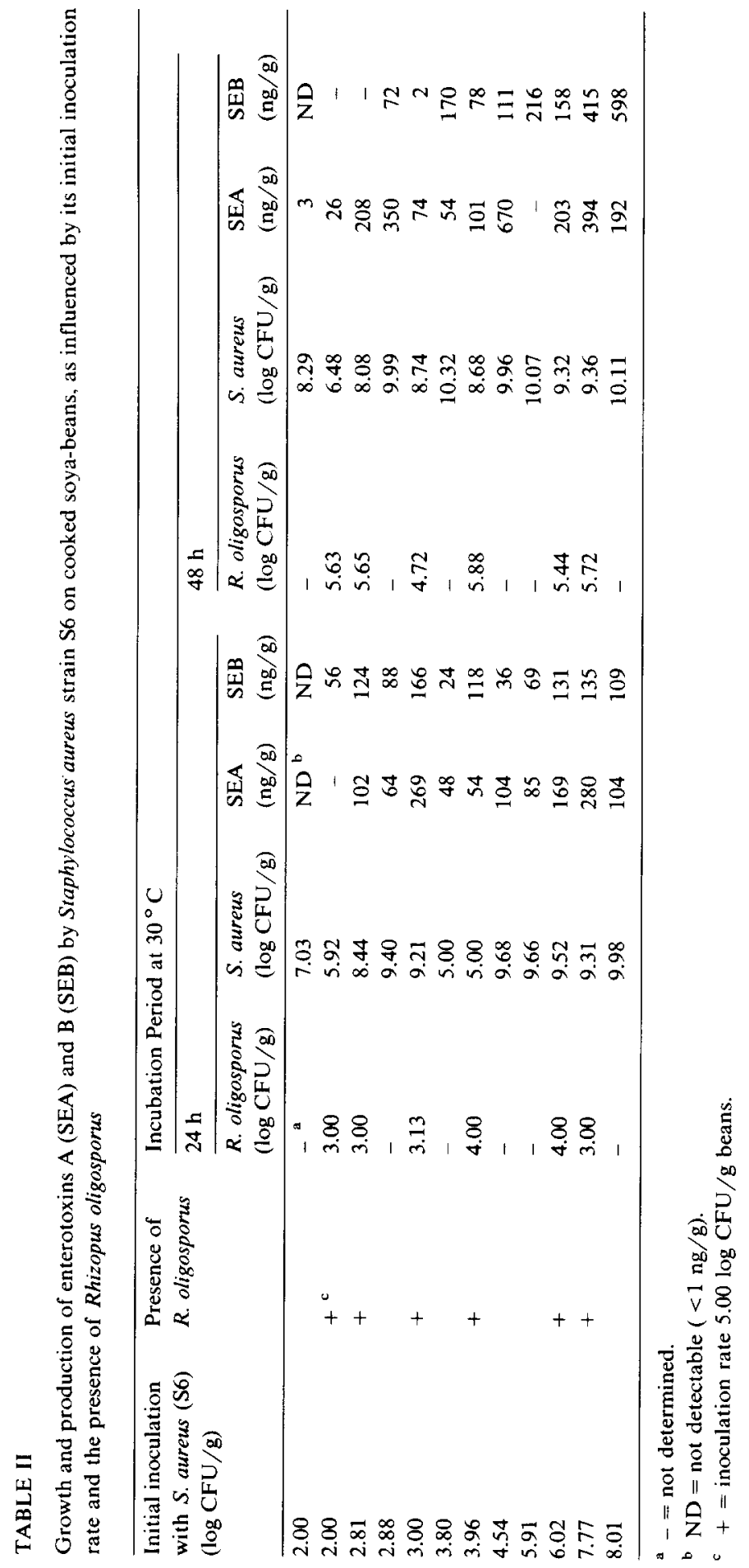




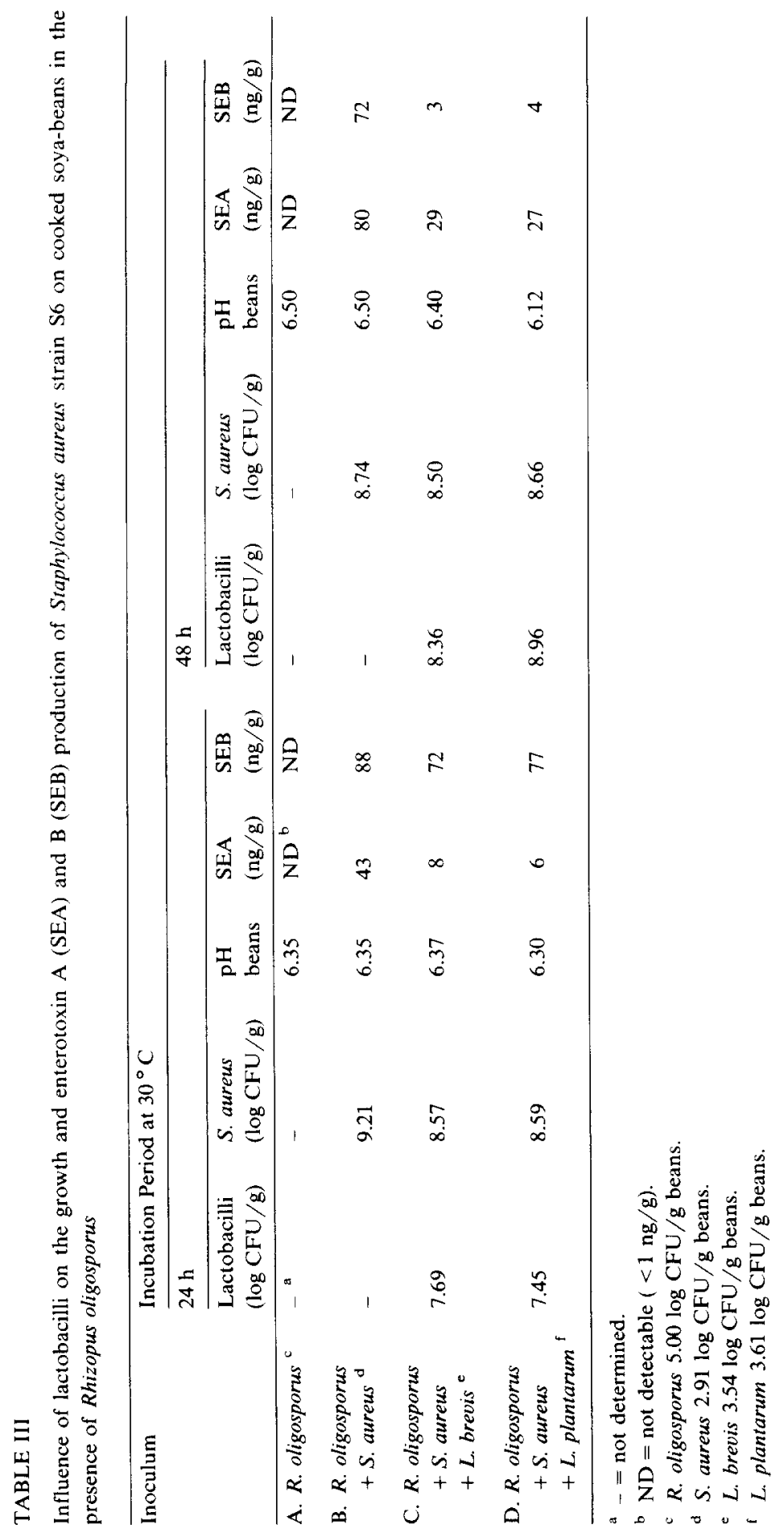


TABLE IV

Influence of atmospheric oxygen concentration on growth and enterotoxin A (SEA) production by Staphylococcus aureus strain $\mathbf{6 6}$ on cooked soya-beans in the presence of Rhizopus oligosporus (incubation $\left.30^{\circ} \mathrm{C}, 48 \mathrm{~h}\right)$.

\begin{tabular}{|c|c|c|c|c|}
\hline \multirow[t]{2}{*}{ Inoculum } & \multicolumn{2}{|l|}{$21 \% \mathrm{O}_{2}$ (air) } & \multicolumn{2}{|l|}{$2 \% \mathrm{O}_{2}$} \\
\hline & $\begin{array}{l}\text { S. aureus } \\
(\log \text { CFU/g) }\end{array}$ & $\begin{array}{l}\text { SEA } \\
(\mathrm{ng} / \mathrm{g})\end{array}$ & $\begin{array}{l}\text { S. aureus } \\
(\log \text { CFU } / g)\end{array}$ & $\begin{array}{l}\text { SEA } \\
(\mathrm{ng} / \mathrm{g})\end{array}$ \\
\hline R. oligosporus ${ }^{\mathrm{c}}$ & $-^{a}$ & $\mathrm{ND}^{\mathrm{b}}$ & - & ND \\
\hline$R$. oligosporus $+S$. aureus $\mathbf{d}$ & 9.15 & 360 & 9.17 & 30 \\
\hline
\end{tabular}

a $-=$ not determined.

${ }^{b} \mathrm{ND}=$ not detectable $(<1 \mathrm{ng} / \mathrm{g})$.

c $R$. oligosporus $5.00 \log \mathrm{CFU} / \mathrm{g}$ beans.

d $S$. aureus $3.71 \log \mathrm{CFU} / \mathrm{g}$ beans.

Staphylococcal enterotoxins have been reported to be rather heat stable (Tatini, 1976). Therefore, the effect of heat treatments such as applied during tempe preparation prior to consumption was investigated. Table $\mathrm{V}$ shows the thermal resistance of $100 \mathrm{ng} / \mathrm{ml}$ pure enterotoxin $\mathrm{A}$ added to $\mathrm{BHI}$ and heated in the same medium. The medium was buffered to have $\mathrm{pH}$ values comparable to those occurring in fresh tempe (Nout et al., 1985). Higher $\mathrm{pH}$ levels tended to increase SEA thermal resistance.

The thermal resistance of similar initial levels of enterotoxins A and B produced by $S$. aureus strain S6 was examined in tempe (final $\mathrm{pH} 6.75$ ). Enterotoxin B had a higher thermal resistance than enterotoxin A; as was reported elsewhere (Tibana et al., 1987). However, we observed a drastic effect of the heating medium on the thermal stability. In tempe, $1 \mathrm{~min}$ at $80^{\circ} \mathrm{C}$ was sufficient to inactivate enterotoxin $\mathrm{A}$ fully and enterotoxin B for $92 \%$. After heating for $1 \mathrm{~min}$ at $100^{\circ} \mathrm{C}$ the enterotoxins were not detectable $(<1 \mathrm{ng} / \mathrm{g})$.

The above enterotoxin determinations had been carried out using monoclonal ELISA antibody-sets (Mab). If heat-induced artefacts would have occurred at epitope level, the use of $\mathrm{Mab}$ might result in erroneously low enterotoxin results. To eliminate such chances, the experiments were repeated with mashed tempe to which

\section{TABLE V}

Influence of $\mathrm{pH}$ on thermal stability of enterotoxin $\mathrm{A}$ added to $\mathrm{BHI}$; SEA levels as $\mathrm{ng} / \mathrm{ml}$

\begin{tabular}{lrrr}
\hline Heat treatment & $\mathrm{pH}$ & & \\
\cline { 2 - 4 } & 6.0 & 6.5 & 7.4 \\
\hline None (control) & 100 & 100 & 100 \\
$80^{\circ} \mathrm{C}, 10 \mathrm{~min}$ & 25 & 35 & 47 \\
$100^{\circ} \mathrm{C}, 10 \mathrm{~min}$ & 22 & 34 & 40 \\
$125^{\circ} \mathrm{C}, 10 \mathrm{~min}$ & 1 & 8 & $-{ }^{-}$ \\
\hline
\end{tabular}

a $-=$ not determined. 
TABLE VI

Influence of $10 \mathrm{~min}$ heating at $100^{\circ} \mathrm{C}$ on $5000 \mathrm{ng} / \mathrm{ml}$ enterotoxin $\mathrm{A}$ (SEA) homogenized in tempe mash

\begin{tabular}{|c|c|}
\hline & $\mathrm{SEA}(\mathrm{ng} / \mathrm{ml})^{a}$ \\
\hline $\begin{array}{l}\text { Before heating: } \\
\text { tempe mash } \\
\text { supernatant of } \\
\text { tempe mash }\end{array}$ & $\left.\begin{array}{l}4860 \\
4860\end{array}\right\}$ recovery $97.2 \%$ \\
\hline $\begin{array}{l}\text { After heating: } \\
\text { tempe mash } \\
\text { supernatant of } \\
\text { tempe mash }\end{array}$ & $\left.\begin{array}{l}12 \\
10^{\mathrm{h}}\end{array}\right\}$ residual enterotoxin $0.3 \%$ \\
\hline
\end{tabular}

a Determined by polyclonal ELISA antibody-sets.

b $20 \mathrm{ml}$ supernatant fed gastro-intestinally, failed to cause vomiting in enterotoxin A-sensitive $M$. fascicularis.

$5000 \mathrm{ng} / \mathrm{ml}$ pure enterotoxin A had been added. Enterotoxin A was now determined using monoclonal as well as polyclonal ELISA antibody-sets. Table VI summarizes the results of the polyclonal test which were identical to those obtained with Mab. Similar extensive heat inactivation of enterotoxin A was observed as previously.

In order to rule out other artefacts which might have interfered with the functioning of both monoclonal and polyclonal ELISA tests, the supernatant of the heated tempe mash was administerd to two monkeys. No vomiting occurred whereas they vomited approx. $2 \mathrm{~h}$ after subsequent administration of $20 \mu \mathrm{g}$ enterotoxin A.

We regard these findings as strongly indicative for the efficient heat inactivation of enterotoxins in tempe. In view of possible application in other food systems, further research on the mechanism(s) of this inactivation continues and is focused on the influence of proteolytic activities of $R$. oligosporus and accompanying microflora (e.g. lactobacilli) in tempe. In particular, it might be possible that the inactivation of enterotoxins as a result of lactobacilli (Table III) is accelerated during the initial warming-up phase of the heat treatment of fresh tempe.

In conclusion, it has been shown that although staphylococcal enterotoxins can be produced during the manufacture of tempe, environmental conditions i.e. accompanying microflora and reduced oxygen concentration inhibit their formation, whereas heat treatments prior to consumption can be expected to adequately inactivate their toxicity.

\section{Acknowledgement}

The technical contributions by E. Koole, A. Bovee, A. Beuvink and T.M.G. Bonants-van Laarhoven are gratefully acknowledged. 


\section{References}

Baggerman, W.I. (1981) A modified rose bengal medium for the enumeration of yeasts and moulds from foods. Eur. J. Appl. Microbiol. 12, 242-247.

Barber, L.E. and Deibel, R.H. (1972) Effect of pH and oxygen tension on staphylococcal growth and enterotoxin formation in fermented sausage. Appl. Microbiol. 24, 891-898.

Ko, S.D. and Hesseltine, C.W. (1979) Tempe and related foods. In: A.H. Rose (Ed.), Economic microbiology, Vol. 4, Microbial Biomass, Academic Press, London, pp. 115-140.

Notermans, S., Boot, R., Tips, P.D. and de Nooy, M.P. (1983a) Extraction of Staphylococcal enterotoxins (SE) from minced meat and subsequent detection of SE with enzyme linked immunosorbent assay (ELISA). J. Food Protect, 46, 238-241.

Notermans, S. and Heuvelman, C.J. (1983b) Combined effect of water activity, pH and sub-optimal temperature on growth and enterotoxin production of Staphylococcus aureus. J. Food Sci. 48, $1832-1835,1840$.

Notermans, S., Tips, P.D. and Heuvelman, C.J. (1984) Einfluss der Milieu-Bedingungen auf das Wachstum von $S$. aureus und die Enterotoxin-Bildung. Fleischwirtschaft 64, 1490-1496.

Notermans, S., Boot, R. and Tatini, S.R. (1987) Selection of monoclonal antibodies for detection of Staphylococcal enterotoxins in heat processed foods. Int. J. Food Microbiol. 5, 49-55.

Nout, M.J.R., Bonants-van Laarhoven, T.M.G., de Dreu, R. and Gerats, I.A.G.M. (1985) The influence of some process variables and storage conditions on the quality and shelf-life of soybean tempe. Antonie van Leeuwenhoek 51, 532-534.

Nout, M.J.R., Beernink, G. and Bonants-van Laarhoven, T.M.G. (1987a) Growth of Bacillus cereus in soya-bean tempeh. Int. J. Food Microbiol. 4, 293-301.

Nout, M.J.R., de Dreu, M.A., Zuurbier, A.M. and Bonants-van Laarhoven, T.M.G. (1987b) Ecology of controlled soya-bean acidification for tempe manufacture. Food Microbiol. 4, 165-172.

Rathbun, B.L. and Schuler, M.L. (1983) Heat and mass transfer in static-solid-substrate fermentations: design of fermentation chambers. Biotechnol. Bioeng. 25, 929-938.

Samson, R.A., van Kooij, J.A. and de Boer, E. (1987) Microbiological safety of commercial tempeh in the Netherlands. J. Food Protect 50, 92-94.

Tatini, S.R. (1976) Thermal stability of enterotoxins in food. J. Milk Food Technol. 39, 432-438.

Tibana, A., Rayman, K., Akhtar, M. and Szabo, S. (1987) Thermal stability of staphylococcal enterotoxins A, B and C in a buffered system. J. Food Protect. 50, 239-242. 